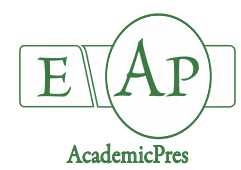

Garcia-Parra M et al. $(2020)$
Notulae Botanicae Horti Agrobotanici Cluj-Napoca 48(4):1742-1755
DOI:10.15835/48412059
Review Article

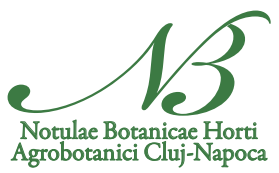

\title{
Chlorophyll fluorescence and its relationship with physiological stress in Chenopodium quinoa Willd.
}

\section{Miguel GARCIA-PARRA ${ }^{1 *}$, Roman STECHAUNER-ROHRINGER ${ }^{1}$, Diego ROA-ACOSTA², Daniel ORTIZ-GONZÁLEZ³, Jorge RAMIREZ-CORREA ${ }^{1}$, Nubia PLAZAS-LEGUIZAMÓN ${ }^{4}$ Andres COLMENARES-CRUZ ${ }^{5}$}

\author{
${ }^{1}$ Universidad del Cauca, Facultad de Ciencias Agrarias, Departamento de Ciencias Agropecuarias, Popayán, Colombia; \\ miguelgarciap@unicauca.edu.co ("corresponding autor); rstechauner@unicauca.edu.co; j.ramirez@unicauca.edu.co \\ ${ }^{2}$ Universidad del Cauca, Facultad de Ciencias Agrarias, Departamento de Agroindustria, Popayán, Colombia; droa@unicauca.edu.co \\ ${ }^{3}$ Corporación Colombiana de Investigación Agropecuaria - AGROSA VIA, Área de fisiología vegetal y cultivos, Palmira, \\ Colombia;dfortiz@agrosavia.co \\ ${ }^{4}$ Fundación Universitaria Juan de Castellanos, Facultad de Ciencias Agrarias y Ambientales, Tunja, Colombia; nplazas@jdc.edu.co \\ ${ }^{5}$ Universidad Nacional Abierta y a Distancia UNAD, Escuela de Ciencias Ambientales Pecuarias y del Medio Ambiente, Tunja, \\ Colombia; ramiro.colmenares@unad.edu.co
}

\begin{abstract}
Photosynthetic activity is a fundamental process in the physiology of plants, and its regulation plays an important role in determining the effect of abiotic factors. Quinoa is a plant species of agronomic and nutritional interest that has been recognized for its adaptability to extreme environmental conditions, however, climate change may result in unfavorable conditions capable of affecting the natural development of this species, which is of great interest culture and research in South America. To evaluate the response of quinoa to stress, techniques could be used that quantify the loss of light energy through its dissipation in the form of heat. However, the measurement of chlorophyll fluorescence is the most widely used and accessible technique for field research, which allows to recognize the relationships between the plant and agroclimatic factors. This review summarizes the physiological effects of heat, radiation, salinity, and nutrient and water availability, as well as their possible interactions on quinoa.
\end{abstract}

Keywords: photosystem II; quinoa; quantum efficiency; reactive oxygen species; stress tolerance

\section{Introduction}

Quinoa, Chenopodium quinoa Willd., Belongs to the Amaranthaceae family and is a pseudocereal native to South America (Bedoya-Perales et al., 2018). This crop is important for human and animal nutrition, as well as for its medicinal and agro-industrial properties (Ahumada et al., 2016; Navruz-Varli and Sanlier, 2016). This is due to the fact that its seeds have a high content of proteins, carbohydrates, lipids and bioactive compounds that favour nutrition of those who consume it (Vazquez-Luna et al., 2019; Roa-Acosta et al., 2020). 
Among the adaptability characteristics of quinoa are its resistance to drought, waterlogging, reduce nutrient availability, radiation changes, edaphic salinity, temperature fluctuations and pests and diseases (García-Parra et al., 2020). That resistance may be due to this plant presents C3 photosynthetic metabolism and genetic rusticity associated with considerable phenotypic plasticity, which allows it to adapt to adverse climatic and edaphic conditions, through modifications in its tissues, organs, productive cycles and therefore, in the physiological and biochemical routes (Becker et al., 2017; Bunce, 2018). However, as other plant species, the quinoa has a range of agroclimatic conditions in which this species develops better, and within this range, an optimal point where, along with its genetic patterns, the best growth and development is attained (PérezBueno et al., 2019).

Outside its optimal range, the stress conditions modify the main physiological activities of plants, mainly their gas exchange through the stomata, which is reflected in the activity of photosystem II (FSII) (Chen, Burke and Xin, 2018). The disturbance of FSII generates reactive oxygen species (ROS), through the accumulation of free radicals in the thylakoid membrane (Kalaji et al., 2014). To avoid the over-excitation of the FSII under conditions of biotic or abiotic stress and the consequent damage of the photosynthetic machinery, part of the energy captured by the reaction centres of the photosystems (photosynthetic pigments) does not take the photochemical pathway, but follows different pathways such as the dissipation of energy in the form of heat and that emitted as light energy through fluorescence. These events occur simultaneously and lead to a decrease in the efficiency of the other two processes (Chen et al., 2018; Maxwell and Johnson, 2000).

The reason to study the fluorescence of chlorophyll is evaluate the function of FSII, mainly during the transport of electrons in the photosynthetic machinery, as well as identify the sensitivity of plants to an external factor through the analysis of the changes in the emission of the red fluorescence of chlorophyll $\alpha$ after subjecting dark adapted plants to lighting, as reported by Kautsky and Hirsch (1931). This methodology has allowed to estimate the photochemical efficiency and thermal dissipation of the photosynthetic reaction centers, becoming an ecophysiological evaluation tool used in cultivable plants such as rice (Oryza sativa), wheat (Triticum aestivum), corn (Zea mays) and pseudo-cereals such as amaranth (Amaranthus sp.) (Bermúdez-Cardona et al., 2014; Wu et al., 2015; Jamalluddin et al., 2018; Tsai et al., 2019). Since then, this technique has been widely used to study the physiological performance of plants, and no research on photosynthesis activity seems complete without chlorophyll fluorescence information (Pérez-Bueno et al., 2019). Thus, this high sensitivity variable allows us to provide information about the interaction between plants and stress-generating environmental factors.

Quinoa has been recognized for its adaptability to extreme agroclimatic conditions (Hinojosa et al., 2018), however, the cultivation of this species outside its environmental range leads to the affectation of the FSII and may favour changes in the fluorescence activity (Murphy and Matanguihan, 2015; Eustis et al., 2020). This study aims to compile existing research information about the fluorescence of chlorophyll as an indicator of stress in quinoa, addressing possible threats to this crop such as water stress, waterlogging, nutritional deficit, salinity, radiation and heat.

\section{Chlorophyll Fluorescence (F-Clo)}

The F-Clo corresponds to the spectrum of light between 680 and $720 \mathrm{~nm}$, emitted by chlorophyll $\alpha$. FClo is used to diagnose the physiological state and photosynthetic activity of the plant, allowing to evaluate adaptability responses or to recognize damage (Kalaji et al., 2014). Thus, the plant responds to external factors through changes in the amount of electromagnetic energy that the photochemical pathway follows, by which it is dissipated in the form of heat or fluorescence, in such a way that when measuring the F-Clo it can be estimated the intrinsic activity of the other two processes (Guidi et al., 2019).

The activation of routes to facilitate the adaptation of plants to different types of stress allow a higher efficiency in energy dissipation through the increase in the cooling capacity in the non-photochemical route, 
without generating alterations in the maximum quantum efficiency of FSII (ratio between variable fluorescence and maximum fluorescence $\mathrm{Fv} / \mathrm{Fm}$ ). Additionally, when the stress level in plants rises considerably, permanent photoinhibition occurs in the $\mathrm{Fv} / \mathrm{Fm}$, while when stress is prolonged, the effects are reflected in the effective quantum yield of FSII ( $\Phi F S I I)$ and photochemical dissipation $(\mathrm{qP})$, which results in a reduction in the electron transport chain and functional detriment of FSII under severe conditions (Murata et al., 2007; Sasi et al., 2018) (Figure 1).

In this way, it is possible to measure fluorescence parameters qualitatively and quantitatively, through non-destructive methods (Maxwell and Johnson, 2000; Pérez-Bueno et al., 2019) which are mostly based on light saturation pulses that excite the antennas of the FSII reaction centres, or on the analysis of images captured with the help of LED lamps or lasers, which estimate the activity of the fractions of fluorescence, allowing to evaluate the response to stress. This is of great interest for crops of alimentary importance, which are produced, in many cases, in areas with marginal conditions (Qin et al., 2013; Zhou et al., 2018; Song et al., 2019; Xu et al., 2020).

Several studies highlight the activity of the fluorescence of chlorophyll under various agri-environmental stress conditions in quinoa that lead to changes in photosynthetic activity (Table 1). However, the physiological versatility of this species is an advantage of productive, academic and scientific interest when compared with other cultivable species, and for which it is highlighted as a promising crop in the face of the effects of climate change (Ruiz et al., 2014; Korres et al., 2016).

The abiotic factors that have the greatest impact on quinoa plants are radiation, heat and nitrogen availability, which surely have an influence in the photosynthetic parameters of the crop under specific agroclimatic conditions (Table 1). Thus, identifying the appropriate cultivars that adapts to specific stress conditions is required when the diversity of biotic and abiotic factors that can affect the species individually or as a whole is uncertain (Hinojosa et al., 2019) (Figure 1).

Table 1. Effect of influencing agroclimatic factors on the performance of chlorophyll fluorescence

\begin{tabular}{|c|c|c|c|c|c|c|}
\hline \multicolumn{2}{|c|}{ Factor } & Cultivar & $\mathrm{Fv} / \mathrm{Fm}$ & ФFSII & qNP & Reference \\
\hline \multirow{2}{*}{ Radiation } & Control & - & 0.82 & 0.73 & & \multirow{2}{*}{$\begin{array}{c}\text { Huarancca Reyes } \\
\text { et al. (2018) }\end{array}$} \\
\hline & 60 min UV-B * 3 days & - & 0.71 & 0.54 & & \\
\hline \multirow{3}{*}{$\begin{array}{l}\text { Salinity and } \\
\text { drought }\end{array}$} & $\begin{array}{c}\text { Salinity (300 } \mathrm{mm} \text { of } \\
\text { salt) }\end{array}$ & - & 0.77 & 0.25 & 0.89 & \multirow{3}{*}{$\begin{array}{l}\text { Killi and Haworth } \\
\text { (2017) }\end{array}$} \\
\hline & $\begin{array}{c}\text { Drought ( } 30 \% \text { of field } \\
\text { capacity }\end{array}$ & - & 0.84 & 0.6 & 0.7 & \\
\hline & Control & - & 0.86 & 0.7 & 0.45 & \\
\hline \multirow{2}{*}{ Salinity } & $300 \mathrm{~mm} \mathrm{NaCl}$ & \multirow{2}{*}{ 'Titicaca' } & 0.8 & - & - & \multirow{2}{*}{$\begin{array}{c}\text { Amjad et al. } \\
(2015)\end{array}$} \\
\hline & Control & & 0.81 & - & - & \\
\hline \multirow{4}{*}{ Heat } & $45^{\circ} \mathrm{C}$ day & \multirow{2}{*}{$17 \mathrm{GR}$} & 0.73 & - & - & \multirow{2}{*}{ Eustis et al. (2020) } \\
\hline & Control & & 0.62 & - & - & \\
\hline & $40^{\circ} \mathrm{C}$ & QQ74 & 0.84 & - & - & \multirow{2}{*}{$\begin{array}{c}\text { Hinojosa et al. } \\
(2019)\end{array}$} \\
\hline & Control & & 0.84 & - & - & \\
\hline \multirow{2}{*}{ Nitrogen } & High nitrogen & \multirow{2}{*}{ Lighthouse } & 0.81 & 0.49 & - & \multirow{2}{*}{$\begin{array}{c}\text { Bascuñán-Godoy } \\
\text { et al. (2018) }\end{array}$} \\
\hline & Low nitrogen & & 0.76 & 0.3 & - & \\
\hline \multirow{2}{*}{ Irrigation } & Irrigated & - & 0.8 & * & - & \multirow{2}{*}{$\begin{array}{c}\text { Hinojosa et al. } \\
(2019)\end{array}$} \\
\hline & Not irrigated & - & 0.83 & * & - & \\
\hline
\end{tabular}

*: variable over time 


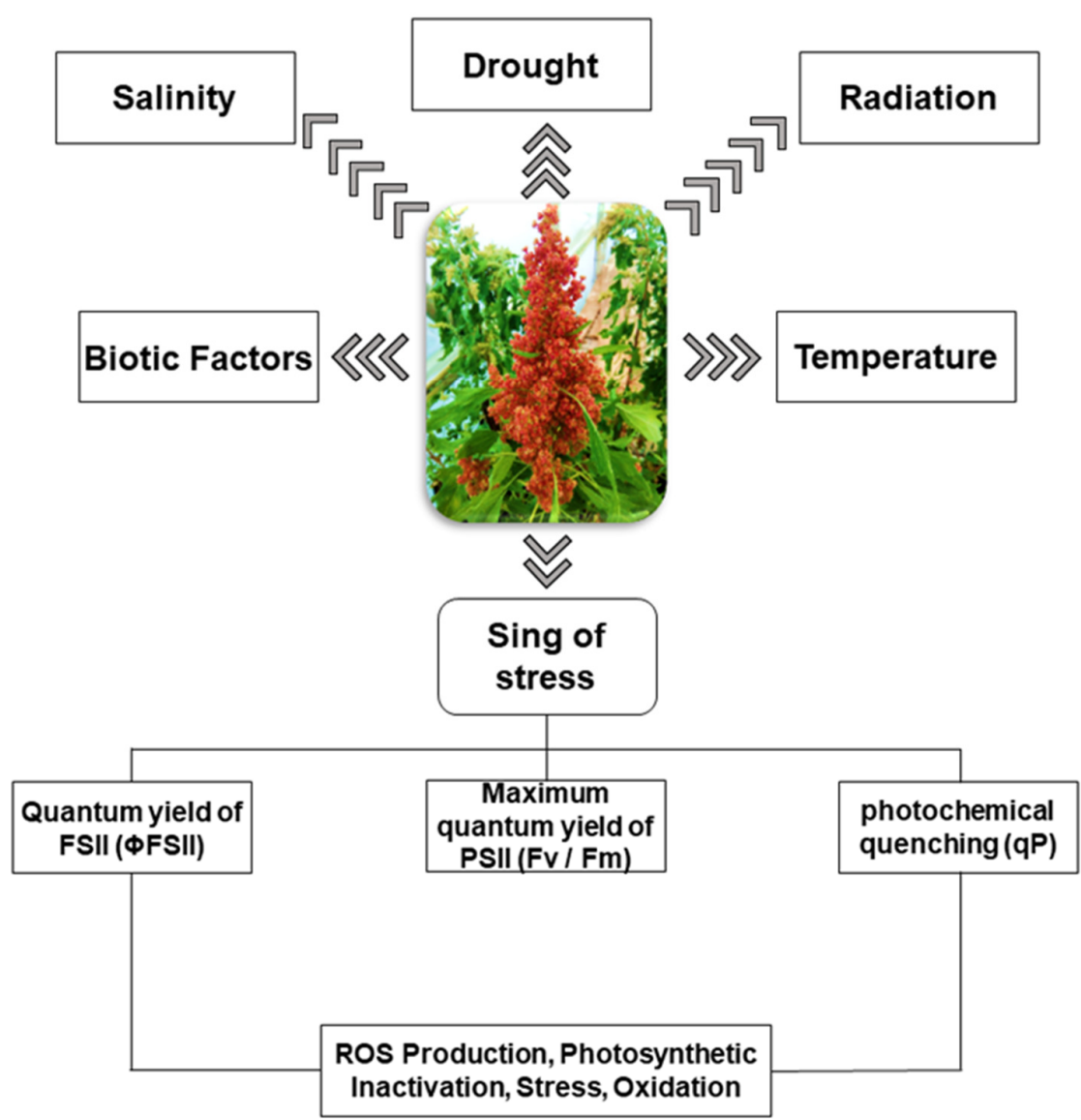

Figure 1. Photosynthetic response of quinoa plants to stress by salinity, drought, radiation, temperature and other biotic factors Source: Authors.

\section{Water Deficit Stress}

Climate change is causing periods with extreme weather extremes in terms of temperature and water deficit (IPCC, 2018), especially in arid regions where quinoa is predominately cultivated, forcing to trust on the genetic diversity of this species to produce in such scenarios (Ruiz et al., 2014). For this reason, quinoa is considered a drought-tolerant species, as it grows in arid regions with annual rainfall of less than $200 \mathrm{~mm}$ (Jacobsen et al., 2006; Alcivar et al., 2018). Its tolerance to drought is attributed to different morphological, physiological and biochemical traits achieved during its evolutionary process under adverse environmental conditions (Issa-Ali et al., 2019). This hardiness makes quinoa a suitable species for cultivation in regions with extreme climatic conditions, where irrigation is not available and farmers depend only on seasonal rains.

It has been reported that the reduction in soil moisture leads quinoa to a decrease in the relative water content of the leaves, which causes the stomatal to close impacting the exchange of gases (González et al., 2009). Therefore, it reduces the rate of photosynthesis, photorespiration, transpiration and absorption of nutrients, along with a decrease in the rate of consumption of ATP and NADPH for CO2 assimilation. This affects the balance between photochemical activity in the FSII and the demand for electrons for photosynthesis, generating an over-excitation in the photosynthetic system and photo-inhibitory damage in the reaction centres (Fghire et al., 2015; Killi and Haworth, 2017). In drought conditions, in vivo chlorophyll fluorescence analyses have provided extensive information on the structure and function of the photosynthetic machinery 
(Hinojosa et al., 2018), mainly about the photochemical phase of FSII, which is strongly influenced by water stress. An additional approach, based on the Bruno and Reto Strasser (JIP) light intensity analysis test in quinoa, has been developed that interprets to identify the fluorescence transit using the continuous excitation fluorometer (Yang et al., 2016). This technique has been used to analyse the rapid transit chlorophyll, which reflects the behaviour of the primary photochemical activity (Kalaji et al., 2014).

In some experiments in quinoa under controlled conditions, the indicators of the photosynthetic capacity of the leaf, such as the maximum quantum efficiency of FSII and the non-photochemical dissipation of chlorophyll $\alpha$ (qNP and NPQ) showed no sensibility to water stress (Winkel et al., 2002; Killi \& Haworth, 2017). Bosque-Sanchez et al. (2003), reported in the "Real" variety that the values of Fv / Fm and qP did not show significant differences in the drought stress treatments between $-0.159 \mathrm{Mpa}$ and $-0.279 \mathrm{Mpa}$ with respect to the irrigated plants, and in all the in cases, Fv / Fm values were higher than 0.812 . Therefore, quinoa shows adaptation to drought conditions. However, these adaptability strategies result in a marked drop in grain yield. Also, Killi and Haworth (2017), found that the plants of the Red Head variety that were brought to germination under controlled conditions, and were subsequently subjected to agroclimatic conditions typical of the central region of Italy (Cesano Morderno) did not present differences in 16 chlorophyll fluorescence parameters (for example: Fv / Fm, ФPSII and NPQ) between the drought and control treatments. The same happened with variables such as the minimum fluorescence yield under adapted dark conditions (Fo), the quantum yield of energy dissipation ( $\Phi \mathrm{DD})$, the absorption of chlorophyll antennas per reaction center (ABS / RC) and the energy flux dissipated for each reaction center (DIo / RC).

Although the fluorescence of chlorophyll does not express the water stress in quinoa, other photosynthetic variables are sensible. However, studies have not yet been able to determine its effect on $\mathrm{qP}$ and QPN activity, and analyses have focused on other techniques such as proline quantification (Yaqoob et al., 2019). In an experiment under greenhouse conditions and with different temperature levels, the Titicaca variety showed a reduction of the $\mathrm{Fv} / \mathrm{Fm}$ mean value to 0.78 in response to the volumetric water content of the soil, corresponding to deficit irrigation and irrigation alternative (Yang et al., 2016). Similar studies demonstrated a rapid recovery of young quinoa plants after a period of drought stress, finding a significant increase in Fv / Fm to 0.84, which suggests that quinoa maintains a high photochemical efficiency in despite the water deficit (Winkel et al., 2002).

Other complementary studies to chlorophyll fluorescence would allow corroborate the effect of drought stress in quinoa, such as the OJIP test, which analyse the activity of the FSII, FSI and cytochrome b6f fraction. In the case of quinoa, it has made possible to identify the most sensitive parameters that describe drought stress, making it a tool to investigate differences in physiological behaviour at the most sensitive sites of action of the photosynthetic machinery. The results obtained by Fghire et al. (2015) during two successive seasons of cultivation of quinoa in Morocco, showed that stress induced changes in the OJIP test.

The OJIP parameter involved several sensitive sites of the FSII and FSI to drought stress. For example, in phenomenological fluxes per time excited cross section (CSm), electron transport (ET0 / CSm) and energy trapping per cross section (TR0 / CSm) were lower under drought stress than in the control. Likewise, the energy fluxes of the acceptor electron $(\Phi \mathrm{R} 0)$ and the quantum efficiency of the electron transport to plastokinase ( $\Phi \mathrm{E} 0)$ and performance index (PI) of the FSII were lower under drought stress and were organized according to its decreased sensitivity to water deficit in the sequence $\Phi \mathrm{R} 0>\Phi E 0$. Another very sensitive indicator of the physiological state of plants was the performance index (PI), which describes the conservation of energy between the photons absorbed by the FSII and the reduction of electron acceptors between systems. Finally, the study concluded that plants at the vegetative stage was more tolerant to drought stress than at growth stages.

There is not available a holistic analysis of the resistance of quinoa to drought since drought treatments have been established using different methodologies (volumetric and gravimetric humidity, soil water tension and crop evapotranspiration). Additionally, the genetic character of each cultivar or variety of quinoa has not been taken into account, which can significantly influence the ecophysiological response and adaptability to 
drought (García-Parra et al., 2020). Consequently, additional studies that include a greater number of genotypes and simultaneous measurements of a physiological, morphological and anatomy should be performed to allow obtaining a more complete knowledge of the response to drought, since the use of chlorophyll fluorescence as indicator variable of stress of water deficit is not enough and could generate inconclusive data to determine the effect of stress by another biotic or abiotic factor. More information can provide possible genotype selection routes within the great diversity that exists in order to maintain their photosynthetic function, exhibiting highly effective protective mechanisms to dissipate excess energy and neutralize oxidative stress. This would allow identifying cultivars with greater resistance to drought stress.

\section{Waterlogging Stress}

Despite that one of the main consequences of climate change is the increasing of droughts in some regions, the years in which the Southern Oscillation (El Niño / La Niña phenomenon) leads to floods affecting the agricultural production by favouring anoxic and hypoxic conditions in the soil (Ramirez-Villegas et al., 2012), limiting the intake of nutrients, the release of exudates and in many cases, the interaction with microorganisms (Kim et al., 2020). Thus, modifications in the amount of water in the soil of the quinoa crops, either by rain or irrigation, can generate effects of agronomic relevance such as alterations in the parameters of growth, development and production (García-Parra et al., 2019).

Jacobsen et al. (2006) report that floods during rainy seasons in tropical quinoa crops cause a significant decrease in production. This, probably due to the low availability of $\mathrm{O} 2$ in the root zone, the rot of roots and even the reduced photosynthetic activity in periods of high cloud cover, for example, when years of La Niña phenomenon occur in Colombia (Fajardo-Rojas, 2019). This climatic factor is of great relevance, since the restrictions in terms of light energy reduce the activity of the FSII, in addition to the energy losses due to heat or fluorescence, so the availability of chemical energy used in the fixation phase of $\mathrm{CO} 2$ is significantly low compared to which occurring in plants under ideal agroclimatic conditions. Thus, there is an alteration of the photosynthetic machinery, the formation of reactive oxygen species and the denaturation of the protein complexes of the thylakoid membranes (Murata et al., 2007).

A waterlogging experiment under controlled conditions had showed a decreases in the agronomic performance of quinoa, highlighting a reduction in the dry weight of foliage and roots, leaf area, leaf nitrogen, chlorophyll content $\alpha$ and $\beta$, as well as a significant increase in the content of starch and soluble protein (González et al., 2009). Under field conditions, the 'BRS Piabiru' quinoa cultivar performed better in terms of plant height, development of basal area, stem weight and number of leaves when it was cultivated in a water regime of up to $563 \mathrm{~mm}$ during its productive cycle. However, under the $647 \mathrm{~mm}$ regime there was a considerable reduction in phenological variables, which indicates sensitivity of quinoa to waterlogging (JaymeOliveira et al., 2017). The same results were obtained in Morocco, where high rainfall and low solar radiation generate problems in the growth of quinoa plants cultivar DO708, and favoured the presence of diseases and weeds (Hirich et al., 2014). This can be attributed to the low absorption of nutrients due to waterlogging, which affects the transport of electrons in the FSII, favouring the dissipation of energy in the form of heat and fluorescence (Kalaji et al., 2018). However, there are other factors associated to high rainfall that affect quinoa, especially during the milky grain phase and physiological maturity, since it favours accelerated germination of the seed in the inflorescence and its production loss (Romero et al., 2018).

Previous studies had showed that the damage to the photosynthetic apparatus is reflected in the growth and development parameters. Also, as mentioned Wu et al. (2015), there are notable reductions in $\mathrm{Fv} / \mathrm{Fm}$, electron transport rate (ETR), $\Phi F S I I$ and qP. It is important to recognize that there is very little research evaluating the effect of waterlogging on the quinoa crop. Given the changing effects of climate, it is necessary to recognize the incidence of this type of stress in the activity of the photosystem. This may favour the cultivation of this species in areas that are influenced by bodies of water at different times of the year. 


\section{Nutritional Deficiency Stress}

An adequate and timely supply of nutrients facilitates the normal plant development. External factors that affect the capture of nutrients by the plant reduce the physiological and productive performance of crops. Various nutrients and micronutrients are involved in the success of plant biochemical and metabolic pathways (Marschner, 2012). Some micronutrients are required in the photosynthetic apparatus, being part of the O2 evolution complex ( $\mathrm{Ca}, \mathrm{Cl}$ and $\mathrm{Mn}$ ), which carries out the oxidation of water and the subsequent transport of electrons towards the cycle of the quinone, plastocyanin and ferredoxin; proteins that structurally contain $\mathrm{Fe}$ and $\mathrm{Cu}$, and consequently, their absence would favour thermal dissipation and fluorescence (Belatik et al., 2013). $P$ is a fundamental component of energy activity and the consolidation of genetic chains, $\mathrm{K}$ as a regulator of stomatal activity and enzymatic synthesis, favouring energy functioning, finally $\mathrm{Ca}$ is as a fundamental element for structuring cell walls, as well as a metabolic signaller (Murphy and Matanguihan, 2015).

Nitrogen makes up the majority of the nutritional requirements of the plant (Fonseca-López et al., 2020). Several studies indicate that stress due to low availability $\mathrm{N}$ in quinoa variety UdeC9 before the senescence phase generates changes in FSII activity, mainly in ФPSII, Fv / Fm, NPQ and damage to the photosynthetic apparatus (Bascunán-Godoy et al., 2018). This damage is attributed to Fo and Fm, which could be highly sensitive in response to the change in the content of chlorophyll $\alpha$ between the beginning of flowering and proximity to senescence. These variables are indicators of stress in plants of alimentary interest, such as rice (Oryza sativa), corn (Zea mays), wheat (Triticum) and barley (Hordeum vulgare) (Huang et al., 2004; Jin et al., 2015; Wang et al., 2016; Carstensen et al., 2018; Tränkner et al., 2018). However, no information is available to explain the availability and absorption of elements in quinoa plants and their relationship with photosynthetic activity. This makes difficult to recognize the particular function of each element, even more when fertilization plays a decisive role in crop management (García-Parra et al., 2019).

\section{Salinity Stress}

Among the causes of salty soils are the characteristics of the parental material of the soil, the presence of saline water bodies, volcanic emanations, and wrong agronomic practices that give rise to the accumulation of chlorides, sulfates, nitrates and carbonates (Machado and Serralheiro, 2017). Salty accumulation in the soil decreases the photosynthetic potential through the alteration of the osmotic balance of cells, stomatal closure, nutrient uptake, and the increase of ROS production, which can be the main cause of oxidative damage to proteins, lipids and DNA.

Quinoa is a facultative halophyte species, an aspect that has been validated through different and highly variable physiological responses among the quinoa genotypes studied. Thus, plants can tolerate electrical conductivity levels from $15 \mathrm{dS} . \mathrm{m}^{-1}$ up to $75 \mathrm{dS} . \mathrm{m}^{-1}$ (Bosque-Sanchez et al., 2003; Hinojosa, 2018; Yan et al., 2020). Salinity significantly affects the tissues and cells of quinoa, and with it, the activity developed in the chloroplasts. This is how in the thylakoid membrane, where the photochemical phase of photosynthesis takes place, important variations have been identified due to the effect of salinity, changes in the photosynthetic rate, transpiration rate, efficiency of the use of photosynthetic water and in the fluorescence activity of chlorophyll (Bosque-Sanchez et al., 2003; Eisa et al., 2012). These alterations have also been reported in rapeseed (Brassica napus), lettuce (Lactuca sativa), barley (Hordeum vulgare), curuba (Passiflora tripartita) and quinoa (Chenopodium quinoa) (Belkhodja et al., 1994; Bacarin et al., 2012; Casierra-Posada et al., 2013; Adhikari et al., 2019; Cai \& Gao, 2020).

Killi and Haworth (2017) recognized that $\mathrm{NaCl}$ contents higher than $300 \mathrm{mM}$ significantly affected Fv / Fm, ФPSII, qNP and NPQ as well as OJIP in the Red head quinoa variety, which was attributed to the damage of the pigment-protein complex in the thylakoid membrane. However, several studies recognized that these variables were not significantly affected by soil salinity in quinoa cultivars such as 'Titicaca', 'Pasankalla', 
'Puno' and 'Amarilla maranganí' (Hariadi et al., 2011; Adolf et al., 2012; Shabala et al., 2013; Bonales-Alatorre et al., 2013).

\section{Radiation Stress (UV-B)}

Solar radiation is one of the main environmental factors that determines the existence and predominance of most plant species since it regulates activities such as growth, development, photosynthesis, photoperiod and even the effect of other environmental factors such as temperature and humidity. The radiation that reaches the earth comprises a range of electromagnetic spectra of violet, blue, green, yellow, orange and red colours that cover wavelengths between 400 and $700 \mathrm{~nm}$ (Photosynthetic Active Radiation (PAR), Carrasco-Ríos, 2009).

The anthropic effect and the changes in biogeochemical cycles have generated the deterioration of the ozone layer during the last decades, and with it, a higher incidence of electromagnetic radiation ranging between 280 and $1000 \mathrm{~nm}$. UV-C (200 and $280 \mathrm{~nm})$ directly affects the genetic structure of organisms. UV-A radiation ( 330 and $400 \mathrm{~nm}$ ) has been found that it is poorly absorbed by O3, implying a high biological risk. Finally, UV-B radiation ( 280 and $320 \mathrm{~nm}$ ) cause alterations in biomolecules such as proteins, nucleic acids and lipids, thus generating effects in tissues that are manifested as morphophysiological modifications in plants (Mandi, 2017). When the UV-B radiation penetrates in the interior of the leaf and is absorbed by the chromophore there is a damage in the FSII, due to it generates alterations in the Mn4Ca cluster through an elongation in atomic distances due to the reduction of $\mathrm{Mn}$, causing the destruction of the metalloprotein group present in the photosystem and production of ROS (Yano and Yachandra, 2014).

UV-B radiation affects the activity of FSII in quinoa. A significant decrease in ФPSII and Fv / Fm had been reported in plants of the Real variety exposed to UV-B radiation, as well as a strong damage in the leaves (Huarancca Reyes et al., 2018). These results were also presented in the cultivar Sajama, which also presented a significant reduction in chlorophyll contents $(\alpha$ and $\beta$ ) and alternation in the photosynthetic system (Hilal et al., 2004). A reduced solar radiation also affects the photosynthetic activity, since it is not possible to excite the accessory pigments of the reaction centres of the FS and consequently, the reduction of chlorophyll molecule does not lose the electron and there is an inactivity process in the photochemical chain (Furbank et al., 2020).

Hinojosa et al. (2018) reported that the UV-B radiation generated a negative effect on chlorophyll fluorescence, pigment synthesis, ROS accumulation and consequently on performance, as well as on the agroclimatic adaptability of quinoa. However, they highlighted the importance of determining the maximum UV-B thresholds that limit the behaviour of quinoa, as well as its influence on other agri-environmental variables.

\section{Heat Stress}

Due to climate change, studies focused on the effect of thermal variations on the physiological and productive performance of quinoa has increased (Ruiz et al., 2014; Bazile et al., 2016). The effect of heat stress is determined by a significant increase in the maximum temperature threshold on plants, causing damage and limitations in growth and development, as a result of the denaturation of proteins and the increase in the fluidity of the membranes (Garcia-Parra et al., 2020) (Figure 2). 


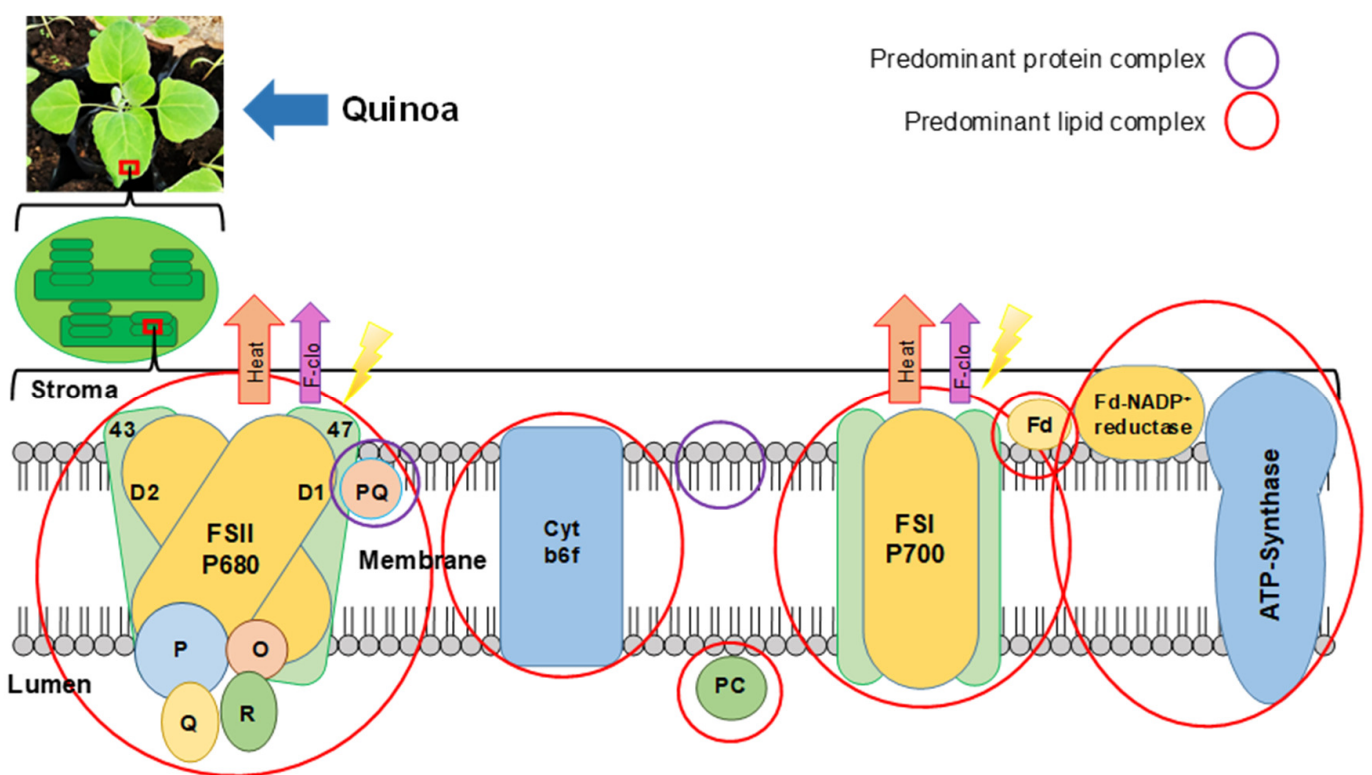

Figure 2. Photosynthetic apparatus and machinery composition PQ: Plastoquinone, PC: Plastocyanin, Fd: Ferredoxin; Source: Authors.

The Figure 2 schematizes the composition of the photosynthetic apparatus in quinoa leaves, from the thylakoid membrane to the protein and lipid complexes that are affected by heat stress. Wahid et al. (2007) reported that the increase in temperatures favours the dissipation of energy in the form of heat and fluorescence, inducing the production of ROS, to the detriment of the stability of the membranes and even affecting the enzymatic reactions, mainly the RuBisCO.

In this sense, Eustis et al. (2020), found that the heat stress tolerance capacity in quinoa changes depending on the cultivar, and tolerance levels stand out up to $45^{\circ} \mathrm{C}$ when the plants are not affected by other types of stress. Thus, the increase in heat is largely related to the photosynthetic rate, stomatal conductance, and $\mathrm{Fv} / \mathrm{Fm}$, and inversely related to the intrinsic activity of water and nocturnal respiration (behaviours that were more marked in cultivars such as 'Kaslaea'). The results of heat adaptability in different quinoa cultivars were reported by Hinojosa et al. (2019), who did not find significant differences in Fv / Fm in cultivars such as 17GR and QQ74, but did find a significant effect on grain production.

Garcia-Parra et al. (2020) established the physiological criteria for the selection of heat-tolerant quinoa cultivars. The following parameters should be taken into account: (a) tolerance to cell damage, (b) photosynthetic activity and stomatal conductance, (c) chlorophyll fluorescence, mainly Fv / Fm and (d) activity of $\mathrm{RuBisCO}$, factors that according to the authors could vary significantly in quinoa plants under desirable conditions, thanks to $\mathrm{C} 3$ metabolism.

\section{Conclusions}

F-Clo can be widely used to assess the stress level in quinoa plants, which makes it an important tool for obtaining information about the effect that abiotic factors such as radiation, water deficit, low nitrogen availability and heat. Salinity is not recognized as a factor that decisively affects chlorophyll fluorescence variables; however, it is considered a secondary factor that conditions other factors that limit the normal physiological activity of this species. F-Clo has been recently evaluated as physiological parameter in quinoa, making difficult to evaluate the effects that waterlogging, salinity, and even some other biotic factors have on quinoa, and thus present a complete view of the limiting factors of this crop. 


\section{Authors' Contributions}

All authors read and approved the final manuscript.

\section{Acknowledgements}

The authors express gratitude to Minciencias (Ministerio de Ciencia, Tecnología e Innovación) invitation for bid Nr. 779/2017. We are also grateful with the Boyacá Department Government, Cauca University and project CIUC-01-2018 carried out by the AOF-JDC.

\section{Conflict of Interests}

The authors declare that there are no conflicts of interest related to this article.

\section{References}

Adhikari ND, Simko I, Mou B (2019). Phenomic and physiological analysis of salinity effects on lettuce. Sensors 19(21):4814. https://doi.org/10.3390/s19214814

Adolf VI, Shabala S, Andersen MN, Razzaghi F, Jacobsen S-E (2012). Varietal differences of quinoa's tolerance to saline conditions. Plant Soil 357(1-2):117-129. https://doi.org/10.1007/s11104-012-1133-7

Ahumada A, Ortega A, Chito D, Benítez R (2016). Saponinas de quinua (Chenopodium quinoa Willd.): un subproducto con alto potencial biológico. Revista Colombiana de Ciencias Químicas Farmaceuticas 45(3):438-469. https://doi.org/10.15446/rcciquifa.v45n3.62043

Alcivar M, Zurita-Silva A, Sandoval M, Muñoz C, Schoebitz M (2018). Reclamation of saline-sodic soils with combined amendments: impact on quinoa performance and biological soil quality. Sustainability 10(9):3083. https://doi.org/10.3390/su10093083

Amjad M, Akhtar SS, Yang A, Akhtar J, Jacobsen S (2015). Antioxidative response of quinoa exposed to iso-osmotic, ionic and non-ionic salt stress. Journal of Agronomy and Crop Science 201(6):452-460. https://doi.org/10.1111/jac.12140

Bacarin MA, Deuner S, da Silva F, Cassol D, Silva DM (2012). Chlorophyll a fluorescence as indicative of the salt stress on Brassica napus L. Brazilian Society of Plant Physiology 23(4):245-253. https://doi.org/10.1590/S167704202011000400001

Bascuñán-Godoy L, Sanhueza C, Hernández CE, Cifuentes L, Pinto K, Álvarez R, González-Teuber M. (2018). Nitrogen supply affects photosynthesis and photoprotective attributes during drought-induced senescence in quinoa. Frontiers in Plant Science 9(994). https://doi.org/10.3389/fpls.2018.00994

Bazile D, Jacobsen S-E, Verniau A (2016). The global expansion of quinoa: trends and limits. Frontiers in Plant Science 7:1-6. https://doi.org/10.3389/fpls.2016.00622

Becker VI, Goessling JW, Duarte B, Caçador I, Liu F, Rosenqvist E, Jacobsen S-E (2017). Combined effects of soil salinity and high temperature on photosynthesis and growth of quinoa plants (Chenopodium quinoa). Functional Plant Biology 44(7):665-678. https://doi.org/10.1071/fp16370

Bedoya-Perales NS, Pumi G, Mujica A, Talamini E, Padula AD (2018). Quinoa expansion in Peru and its implications for land use management. Sustainability (Switzerland) 10(2):532. https://doi.org/10.3390/su10020532

Belatik A, Hotchandani S, Carpentier R (2013). Inhibition of the water oxidizing complex of photosystem II and the reoxidation of the quinone acceptor $\mathrm{QA}$ by $\mathrm{Pb} 2+$. Plos One 137:151-155. https://doi.org/10.1371/journal.pone.0068142

Belkhodja R, Morales F, Abadia A, Cómez-Aparisi J, Abadia J (1994). Chlorophyll fluorescence as a possible tool for salinity tolerance screening in barley (Hordeum vulgare L.). Plant Physiology 104(2):667-673. https://doi.org/10.1104/pp.104.2.667 
Bermúdez-Cardona MB, Américo J, Filho W, Rodrigues FÁ (2014). Leaf gas exchange and chlorophyll a fluorescence in maize leaves infected with Stenocarpella macrospora. Biochemistry and Cell Biology 105(1):26-34. https://doi.org/10.1094/PHYTO-04-14-0096-R

Bonales-Alatorre E, Shabala S, Chen Z, Pottosin I (2013). Reduced tonoplast fast-activating and slow-activating channel activity is essential for conferring salinity tolerance in a facultative halophyte, quinoa. Plant Physiology 162(2):940-952. https://doi.org/10.2307/41943275

Bosque-Sanchez H, Lemeur R, Van Damme P, Jacobsen S-E (2003). Ecophysiological analysis of drought and salinity stress of quinoa (Chenopodium quinoa Willd.). Food Reviews International 19(1-2):111-119. https://doi.org/10.1081/FRI-120018874

Bunce JA (2018). Thermal acclimation of the temperature dependence of the VCmax of Rubisco in quinoa. Photosynthetica 56(4):1171-1176. https://doi.org/10.1007/s11099-018-0799-3

Cai Z-Q, Gao Q (2020). Comparative physiological and biochemical mechanisms of salt tolerance in five contrasting highland quinoa cultivars. BMC Plant Biology 20(1):1-15. https://doi.org/10.1186/s12870-020-2279-8

Carrasco-Ríos L (2009). Efecto de la radiación Ultravioleta-B en plantas [Effect of Ultraviolet-B radiation on plants]. IDESIA 27(3):59-76. http://dx.doi.org/10.4067/S0718-34292009000300009

Carstensen A, Herdean A, Schmidt B, Sharma A, Spetea C, Pribil M, ... Husted S (2018). The impacts of phosphorus deficiency on the photosynthetic electron transport chain. Plant Physiology 177(1):271-284. https://doi.org/10.1104/pp.17.01624

Casierra-Posada F, Peña-Olmos J, Vaughan G (2013). Photochemical efficiency of photosystem II and growth in banana passionfruit plants (Passiflora tripartita (Juss.) var. mollissima (Kunt) L. H. Bailey under salt stress. Acta Agronómica 62(1):21-26.

Chen J, Burke JJ, Xin Z (2018). Chlorophyll fluorescence analysis revealed essential roles of FtsH11 protease in regulation of the adaptive responses of photosynthetic systems to high temperature. BMC Plant Biology 12(1):1-10. https://doi.org/10.1186/s12870-018-1228-2

Eisa S, Hussin S, Geissler N, Koyro HW (2012). Effect of $\mathrm{NaCl}$ salinity on water relations, photosynthesis and chemical composition of quinoa (Chenopodium quinoa Willd.) as a potential cash crop halophyte. Australian Journal of Crop Science 6(2):357-368.

Eustis A, Murphy K, Barrios-Masias F (2020). Leaf gas exchange performance of ten quinoa genotypes under a simulated heat wave. Plants 9(1)81. https://doi.org/10.3390/plants9010081

Fajardo-Rojas A (2019). Variabilidad climática y disponibilidad hídrica en los valles de Ubaté, Chiquinquira y Alto Chicamocha, Colombia [Climate variability and water availability in the valleys of Ubaté, Chiquinquira and Alto Chicamocha, Colombia.] Acta Agronómica 68(3):182-195. https://doi.org/10.15446/acag.v68n3.69082

Fghire R, Anaya F, Ali OI, Benlhabib O, Ragab R, Wahbi S (2015). Physiological and photosynthetic response of quinoa to drought stress. Chilean Journal of Agricultural Research 75(2):174-183. https://doi.org/10.4067/S071858392015000200006

Fonseca-López D, Quila-Vivas N, Balaguera-López HE (2020). Técnicas aplicadas en la investigación agrícola para cuantificar la fijación de nitrógeno: una revisión sistemática [Techniques applied in agricultural research to quantify nitrogen fixation: a systematic review]. Corpoica Ciencia y Tecnología Agropecuaria 21(e1342):1-19. https://doi.org/10.21930/rcta.vol21_num1_art:1342

Furbank RT, Sharwood R, Estavillo GM, Silva-Perez V, Condon A (2020). Photons to food: genetic improvement of cereal crop photosynthesis. Journal of Experimental Botany 71(7):2226-2238. https://doi.org/10.1093/jxb/eraa077

Garcia-Parra M, Roa-Acosta D, Stechauner-Rohringer R, García-Molano JF, Bazile D, Plazas-Leguizamón N (2020). Effect of temperature on the growth and development of quinoa plants (Chenopodium quinoa Willd.): A review on a global scale. Sylwan 164(5):411-433.

García-Parra M, García-Molano J, Deaquiz-Oyola Y (2019). Physiological performance of quinoa (Chenopodium quinoa Willd.) under agricultural climatic conditions in Boyaca, Colombia. Agronomía Colombiana 37(2):144-152. https://doi.org/10.15446/agron.colomb.v37n2.76219

García-Parra M, Zurita-Silva A, Stechauner-Rohringer R, Roa-Acosta D, Jacobsen S-E (2020). Quinoa (Chenopodium quinoa Willd.) and its relationship with agroclimatic characteristics: A Colombian perspective. Chilean Journal of Agricultural Research 80(2):290-302. https://doi.org/10.4067/S0718-58392020000200290

González JA, Gallardo M, Hilal M, Rosa M, Prado FE (2009). Physiological responses of quinoa (Chenopodium quinoa Willd.) to drought and waterlogging stresses: dry matter partitioning. Botanical Studies 50:35-42. 
Guidi L, Piccolo EL, Landi M (2019). Chlorophyll fluorescence, photoinhibition and abiotic stress: does it make any difference the fact to $\mathrm{Be}$ a C3 or C4 species? Frontiers in Plant Science 10:174. https://doi.org/10.3389/fpls.2019.00174

Hariadi Y, Marandon K, Tian Y, Jacobsen S-E, Shabala S (2011). Ionic and osmotic relations in quinoa (Chenopodium quinoa Willd.) plants grown at various salinity levels. Journal of Experimental Botany 62(1):185-193. https://doi.org/10.1093/jxb/erq257

Hilal M, Parrado F, Rosa M, Gallardo M, Orce L, Massa EM, ... Prado FE (2004). Epidermal lignin deposition in quinoa cotyledons in response to UV-B radiation. Photochemistry and Photobiology 79(2):205-2010. https://doi.org/10.1111/j.1751-1097.2004.tb00011.x

Hinojosa L, Kumar N, Gill KS, Murphy KM (2019). Spectral reflectance indices and physiological parameters in quinoa under contrasting irrigation regimes. Crop Science 59(5):1927-1944. https://doi.org/10.2135/cropsci2018.11.0711

Hinojosa L (2018). Effect of heat and drought stress in quinoa (Chenopodium quinoa Willd.). PhD Thesis. Washington State University.

Hinojosa L, González J, Barrios-Masias F, Fuentes F, Murphy K (2018). Quinoa abiotic stress responses: a review. Plants 7(4):106. https://doi.org/10.3390/plants7040106

Hinojosa L, Matanguihan JB, Murphy KM (2019). Effect of high temperature on pollen morphology, plant growth and seed yield in quinoa (Chenopodium quinoa Willd.). Journal of Agronomy and Crop Science 205(1):33-45. https://doi.org/10.1111/jac.12302

Hinojosa L, Sanad M, Jarvis D, Steel P, Murphy K, Smertenko A (2019). Impact of heat and drought stress on peroxisome proliferation in quinoa. The Plant Journal 99(6):1144-1158. https://doi.org/10.1111/tpj.14411

Hirich A, Allah-Choukr R, Jacobsen S-E (2014). Quinoa in Morocco - effect of sowing dates on development and yield. Journal of Agronomy and Crop Science 200(5):371-377. https://doi.org/10.1111/jac.12071

Huang Z-A, Juang D-A, Yang Y, Sun J-W, Jin S-H (2004). effects of nitrogen deficiency on gas exchange, chlorophyll fluorescence, and antioxidant enzymes in leaves of rice plants. Photosynthesis Research 42(3):357-364.

Huarancca Reyes T, Scartazza A, Castagna A, Cosio EG, Ranieri A, Guglielminetti L (2018). Physiological effects of short acute UVB treatments in Chenopodium quinoa Willd. Scientific Reports 126(6):787-794. https://doi.org/10.1038/s41598-017-18710-2

Issa-Ali O, Fghire R, Anaya F, Benlhabib O, Wahbi S (2019). Physiological and morphological responses of two quinoa cultivars (Chenopodium quinoa Willd.) to drought stress. Gesunde Pflanzen 71(2):123-133. https://doi.org/10.1007/s10343-019-00460-y

Jacobsen S, Mujica A, Jensen CR (2006). The resistance of Quinoa (Chenopodium quinoa Willd.) to adverse abiotic factors. Food Reviews International 19(1-2):99-109. https://doi.org/10.1081/FRI-120018872

Jamalluddin N, Massawe FJ, Symonds RC (2018). Transpiration efficiency of Amaranth (Amaranthus sp.) in response to drought stress. Journal of Horticultural Science and Biotechnology 94(4):448-459. https://doi.org/10.1080/14620316.2018.1537725

Jayme-Oiveira A, Ribeiro W, Ramos R, Ziviani M, Jakelaitis G (2017). Amaranth, quinoa, and millet growth and development under different water regimes in the Brazilian Cerrado. Pesquisa Agropecuaria Brasileira 25(1):182-187. https://doi.org/10.1590/S0100-204X2017000800001

Jin X, Yang G, Tan C, Zhao C (2015). effects of nitrogen stress on the photosynthetic CO2 assimilation, chorophyll fluorescence, and sugar-nitrogen ratio in corn. Scientific Reports 5(1):1-9. https://doi.org/10.1038/srep09311

Kalaji HM, Baba W, Gediga K, Goltsev V, Samborska I, Cetner M, ... Kompala-Baba A (2018). Chorophyll fluorescence as tool for nutrient status identification in rapeseed plants. Photosynthesis Research 136(3):329-343. https://doi.org/https://doi.org/10.1007/s11120-017-0467-7

Kalaji HM, Schansker G, Ladle RJ, Goltsev V (2014). Frequently asked questions about in vivo chlorophyll fluorescence: practical issues. Photosynthesis Research 122(2):121-158. https://doi.org/10.1007/s11120-014-0024-6

Kautsky H, Hirsch A (1931). Neue Versuche zur Kohlensäureassimilation [New attempts at carbon dioxide assimilation]. Naturwissenschaften 19:964-964. https://doi.org/https://doi.org/10.1007/BF01516164

Killi D, Haworth M (2017). Diffusive and metabolic constraints to photosynthesis in quinoa during drought and salt stress. Plants 6(4):49. https://doi.org/10.3390/plants6040049

Kim Y, Shahzad R, Lee I-J (2020). Regulation of flood stress in plants. In: Plant life under changing environment. pp 157173. https://doi.org/https://doi.org/10.1016/C2018-1-02300-8 
Korres NE, Norsworthy JK, Tehranchian P, Gitsopoulos TK, Loka DA, Oosterhuis DM, ... Palhano M (2016). Cultivars to face climate change effects on crops and weeds: a review. Agronomy for Sustainable Development 36(1):12. https://doi.org/10.1007/s13593-016-0350-5

Machado R, Serralheiro RP (2017). Soil salinity: effect on vegetable crop growth. management practices to prevent and mitigate soil salinization. Horticulturae 3(2):30. https://doi.org/10.3390/horticulturae3020030

Mandi S (2017). Natural UV radiation in enhancing survival value and quality of plants. Springer.

Marschner P (2012). Mineral nutrition of higher plants (Third). Boston, Elsevier.

Masson-Delmotte TWV, Zhai P, Pörtner HO, Roberts D, Skea J, Shukla PR, ... Connors S (2018). IPCC, 2018: Summary for Policymakers. In: Global warming of 1.5 C. An IPCC Special Report on the impacts of global warming of 1.5 C above pre-industrial levels and related global greenhouse gas emission pathways, in the context of strengthening the global. World Meteorological Organization, Geneva, Tech. Rep.

Maxwell K, Johnson GN (2000). Chlorophyll fluorescence - a practical guide. Journal of Experimental Botany 51(345):659-668.

Murata N, Takahashi S, Nishiyama Y, Allakhverdiev SI (2007). Photoinhibition of photosystem II under environmental stress. Biochimica et Biophysica Acta - Bioenergetics 1767(6):414-421. https://doi.org/10.1016/j.bbabio.2006.11.019

Murphy K, Matanguihan J (2015). quinoa improvement and sustainable production. I. Jhon Wiley \& Sons (Ed.), New Jersey.

Navruz-Varli S, Sanlier N (2016). Nutritional and health benefits of quinoa (Chenopodium quinoa Willd.). Journal of Cereal Science 69:371-376. https://doi.org/10.1016/j.jcs.2016.05.004

Pérez-Bueno M, Pineda M, Barón M (2019). Phenotyping Plant responses to biotic stress by chlorophyll fluorescence imaging. Frontiers in Plant Science 10:1135. https://doi.org/10.3389/fpls.2019.01135

Qin L, Guo S, Ai W, Tang Y, Cheng Q, Chen G (2013). Effect of salt stress on growth and physiology in amaranth and lettuce: Implications for bioregenerative life support system. Advances in Space Research 49(10):1506-1519. https://doi.org/10.1016/jasr.2012.09.025

Ramirez-Villegas J, Salazar M, Jarvis A, Navarro-Racines CE (2012). A way forward on adaptation to climate change in Colombian agriculture: perspectives towards 2050. Climatic Change 115(3-4):611-628. https://doi.org/10.1007/s10584-012-0500-y

Roa-Acosta DF, Bravo-Gómez JE, García-Parra MA, Rodríguez-Herrera R, Solanilla-Duque JF (2020). Hyper-protein quinoa flour (Chenopodium Quinoa Wild): Monitoring and study of structural and rheological properties. LWT - Food Science and Technology 121(108952):1-7. https://doi.org/10.1016/j.lwt.2019.108952

Romero G, Heredia A, Chaparro-Zambrano H (2018). Germinative potential in quinoa (Chenopodium quinoa Willd.) seeds stored under cool conditions. Revista U.D.C.A Actualidad \& Divulgación Científica 21(2):341-350.

Ruiz KB, Biondi S, Oses R, Acuña-Rodríguez IS, Antognoni F, Martinez-Mosqueira EA, ... Molina-Montenegro MA (2014). Quinoa biodiversity and sustainability for food security under climate change. A review. Agronomy for Sustainable Development 34(2):349-359. https://doi.org/10.1007/s13593-013-0195-0

Sasi S, Venkatesh J, Daneshi RF, Gururani MA (2018). Photosystem II extrinsic proteins and their putative role in abiotic stress tolerance in higher plants. Plants 7(4):100. https://doi.org/10.3390/plants 7040100

Shabala S, Hariadi Y, Jacobsen S-E (2013). Genotypic difference in salinity tolerance in quinoa is determined by differential control of xylem Na+ loading and stomatal density. Journal of Plant Physiology 169(16):1623-1630. https://doi.org/10.1016/j.jplph.2013.01.014

Song X, Zhou G, Ma B, Wu W, Ahmad I, Zhu G, ... Jiao X. (2019). Nitrogen application improved photosynthetic productivity, chlorophyll fluorescence, yield and yield components of two oat genotypes under. Agronomy 9(3):115. https://doi.org/10.3390/agronomy9030115

Tomás A (2015). Utilización de medida de fluorescencia de la clorofila para monitorear el estado nutricional y estimar el potencial enológico en viñedos afectados por clorosis férrica. Tesis de PhD. Universidad de Valladolid.

Tränkner M, Tavakol E, Jákli B (2018). Functioning of potassium and magnesium in photosynthesis, photosynthate translocation and photoprotection. Physiologia Plantarum 163(3):414-431. https://doi.org/10.1111/ppl.12747

Tsai Y, Chen K, Cheng T, Lee C, Lin S, Tung C (2019). Chlorophyll fluorescence analysis in diverse rice varieties reveals the positive correlation between the seedlings salt tolerance and photosynthetic efficiency. BMC Plant Biology 19(1):403. https://doi.org/10.1186/s12870-019-1983-8 
Vazquez-Luna A, Cortés V, Carmona F, Díaz-Sobac R (2019). Quinoa leaf as a nutritional alternative. Ciencia e Investigación Agraria 46(2):137-143. https://doi.org/10.7764/rcia.v46i2.2098

Wahid A, Gelani S, Ashraf M, Foolad MR (2007). Heat tolerance in plants: An overview. Environmental and Experimental Botany 61(3):199-223. https://doi.org/10.1016/j.envexpbot.2007.05.011

Wang X, Wang L, Shangguan Z (2016). Leaf gas exchange and fluorescence of two winter wheat varieties in response to drought stress and nitrogen supply. PLoS ONE 11(11):e0165733. https://doi.org/10.1371/journal.pone.0165733

Winkel T, Méthy M, Thenot F (2002). Radiation use efficiently, cholophyll fluorescence, and reflectance indices. Photosynthetica 40(2):227-232. https://doi.org/https://doi.org/10.1023/A:1021345724248

Wu X, Tang Y, Li C, Wu C, Huang G (2015). Chlorophyll fluorescence and yield responses of winter wheat to waterlogging at different growth stages. Plant Production Science 18(3):284-294. https://doi.org/10.1626/pps.18.284

Xu Q, Ma X, Lv T, Bai M, Wang Z, Niu J (2020). Effects of water stress on fluorescence parameters and photosynthetic characteristics of drip irrigation in rice. Water 12(1):289. https://doi.org/10.3390/w12010289

Yan H, Shah SS, Zhao WE, Liu F (2020). Variations in water relations, stomatal characteristics, and plant growth between quinoa and pea under salt-stress conditions. Pakistan Journal of Botany 52(1):1-7. https://doi.org/10.30848/PJB2020-1(8)

Yang A, Akhtar SS, Amjad M, Iqbal S, Jacobsen S-E (2016). Growth and physiological responses of quinoa to drought and temperature stress. Journal of Agronomy and Crop Science 202(6):445-453. https://doi.org/10.1111/jac.12167

Yano J, Yachandra V (2014). Mn4Ca Cluster in photosynthesis: where and how water is oxidized to dioxygen. Chemical Review 4205(1):4175-4205. https://doi.org/10.1021/cr4004874

Yaqoob H, Akram NA, Iftikhar S, Ashraf M, Khalid N, Sadiq M, ... Ahmad P (2019). Seed pretreatment and foliar application of proline regulate morphological, physio-biochemical processes and activity of antioxidant enzymes in plants of two cultivars of quinoa (Chenopodium quinoa Willd.). Plants 8(12):588. https://doi.org/doi:10.3390/plants8120588

Zhou R, Wu Z, Wang X, Rosenqvist E, Wang Y, Zhao T, Ottosen C (2018). Evaluation of temperature stress tolerance in cultivated and wild tomatoes using photosynthesis and chlorophyll fluorescence. Horticulture, Environment, and Biotechnology 59(4):499-509. https://doi.org/10.1007/s13580-018-0050-y
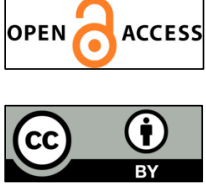

The journal offers free, immediate, and unrestricted access to peer-reviewed research and scholarly work. Users are allowed to read, download, copy, distribute, print, search, or link to the full texts of the articles, or use them for any other lawful purpose, without asking prior permission from the publisher or the author.

License - Articles published in Notulae Botanicae Horti Agrobotanici Cluj-Napoca are Open-Access, distributed under the terms and conditions of the Creative Commons Attribution (CC BY 4.0) License. (c) Articles by the authors; UASVM, Cluj-Napoca, Romania. The journal allows the author(s) to hold the copyright/to retain publishing rights without restriction. 